\title{
European setback at Milan
}

\section{Disagreement among members of the European Communities last weekend at Milan will hamper the cause of technical collaboration. Modest plans are now in order.}

All the high hopes of the past several weeks that Eurcpe would find a way of making itself technologically competitive with the rest of the world have been thrown into limbo. That is the simplest reading of the chaos into which the affairs of the European Communities have been plunged by last weekend's summit meeting at Milan. Formally, the heads of government did manage to agree that something should be done to put flesh on the bones of the French Eureka project; the French government is to call a meeting of foreign and research ministers in the second half of this month at which they will attempt to decide how the Eureka enterprise should work. The present plan is that governments other than the twelve members and putative members of the Communities should be free to participate if they wish. (Austria, Sweden and Switzerland are likely to be welcomed as outsiders.) The meeting is not intended to choose projects for collaboration but, rather, to define a mechanism which. governments agreed at Milan. should be above all flexible. The obvious snag is that while European governments are at loggerheads among themselves about the political future of their community, agreements on even technological collaboration are bound to seem unreal.

Ironically, the fiasco at Milan appears to have sprung from a sensible if belated recognition by European governments that the time has come to make what is often called the common market operate as such. Europe cannot be surprised that it is technologically often at a disadvantage in comparison with Japan and the United States when the present restraints on trade and competition persist. During the past few months. the European Commission has been hard at work on the definition of the steps that must be taken to dismantle these artificial and often illegal impediments to efficiency. Mercifully, all governments appear to agree that getting rid of these restrictions will be impossible while member states hang onto the principle that all decisions about the working of the Communities must be reached unanimously (or that any dissident member may veto an unpalatable proposal, as West Germany vetoed last month's agreement that cereal prices should be reduced). This is why the British went to Milan pushing for a package of procedural reforms that would have restricted a government's right to use the veto, and otherwise have made the community's decisionmaking more orderly. France and West Germany, on the other hand, with the unexpected backing of Italy, pushed instead for a revision of the Treaty of Rome, the legal instrument which is the foundation of the European Economic Community. The outcome is a fuzzy decision that. later in the year, there should be a formal conference to consider amendments to the treaty. This is a recipe both for delay and for further quarrelling within the community, if only because governments represented at this meeting will be able to veto any of the decisions it may reach. Especially because there is as yet no word on when or how the

\section{Biological manuscripts}

Contributors are reminded that, with the transfer of the Biological Sciences Editor to the Washington office, it will be helpful if they will in future send four copies of all manuscripts offered for publication, either (as at present) to London or Washington. conference will be organized. the upshot is bound to be that no framework for technological collaboration in Europe can be assured by the time of the Eurekat meeting later this month.

Worse than that, the Milan meeting cannot but further sour relationships between European governments. Only occasionally in the past decade does it seem to have been possible for the heads of the European governments to meet without uncovering some obdurate disagreement. Last weekend's fracas at Milan will have further emphasized the degrees to which different members of the European Communities harbour different but serious reservations about the enterprise to which they belong. The European Communities have survived for the past thirty years chiefly because there has been a general recognition that attempts to force the pace towards European integration will be self-defeating if individual members are faced with politically unpalatable decisions. The attempt that will be made. later in the year, to force through amendments to the Treaty of Rome is bound to throw sand into the machinery of all kinds of European collaboration. Eureka included.

What can be salvaged from this mess? The best way forward for Eureka will be to postpone final decisions about the content of the programme of research and development on which Europe collectively seems eager to embark. In due course. it may emerge that there are technical projects of such originality that they promise opportunities for particular European industries to become genuinely competitive. Schemes for attempting to beat IBM at the game which it has played successfully over past decades should not. at this stage. qualify. It should also by now be clear that Eureka should not become one of those ambitious community projects in which there is some central pot of gold contributed by governments for a share of which companies in member states are encouraged to compete. The best strategy will be to use such public funds as there mav be for supporting to provide the infrastructure from which novel technology may spring. Although President Mitterrand's clear wish (and political need) to clothe Eureka ambitiously would not be satisfied by, for example, public support for research and teaching institutions that could make good deficiencies in Europe. that may be the wisest course after the disaster at Milan.

\section{Where the onus lies}

\section{British science should make the government shoulder responsibility for political decisions.}

ON the working hypothesis that the British government will not increase the funds earmarked for research in the next financial year (beginning in April 1986). researchers had better take what steps they can to save their own skins. In the next few months. the burden will fall chiefly on the Advisory Board for the Research Councils (ABRC). which technically exists to advise the Department of Education and Science on how the inadequate funds available should be divided. Two immediate issues must be settled. ABRC has to say how it would have the government respond to the report of the Kendrew Committee. which advocated a fortnight ago that Britain should pull out of European collaboration in high-energy physics (chiefly through CERN) unless there can be negotiated a 25 per cent reduction of the 